Boban Stojanović, Ph.D.

University of Niš, Faculty of Economy, Serbia

stojanovic@ni.ac.rs

Zorana Kostić

University of Niš, Faculty of Economy, Serbia

zoksinis@gmail.com

\title{
THE WESTERN BALKANS: ECONOMIC POTENTIALS AND LABOUR MARKET GAPS ON THE SUSTAINABLE PATH TO EUROPEAN UNION
}

Received: October 15, 2018

Accepted: December 20, 2018

Preliminary communication

\begin{abstract}
One of the main aims of the paper is to estimate how sustainable is the transition of Western Balkans to the European union and to present scenario analysis for this region. The new momentum for real chance of success in accession process towards European Union depends on both economic results and political will of the governing bodies. In this respect, more flexible and differentiated approach towards the Western Balkans is required to enable the exploitation of economic potentials and reduction labour market gaps. Western Balkan Countries' ability to assume obligations of EU membership are summarized by using selected indicators which indicate the readiness of each country to integrate and to harmonize economic system. Taking into account the six transition qualities (Competitive, Well-governed, Green, Inclusive, Resilient, Integrated),the ranking of the Western Balkans countries was performed. By calculating the Pearson coefficient for economic potential (measured by GDP per capita) and the labor market indicator (Average monthly gross wages) in the period 2012-2017. for six Western Balkan countries, it is concluded that there is strong positive correlation between them. The basic research question which has been tested during the research is whether country rank based on transition qualities, respond to country rank based on labour market indicators (such as Average monthly gross wages).
\end{abstract}

Keywords: Western Balkans, transition qualities, economic potential, labour market indicators

JEL: E24, F6 


\section{INTRODUCTION}

In 2018, the European Commission adopted a strategy for "A credible enlargement perspective for and enhanced EU engagement with the Western Balkans", confirming the European future of the region as a geostrategic investment in a stable, strong and united Europe based on common values. The Strategy spells out the priorities and areas of cooperation, addressing the specific challenges the Western Balkans face, in particular the need for fundamental reforms and good neighbourly relations. A credible enlargement perspective requires sustained efforts and irreversible reforms. Progress along the European path is an objective and merit-based process which depends on the concrete results achieved by each individual country. The Strategy also underlines the need for the EU to be prepared to welcome new members once they have met the criteria.(European Commission, 2018)

The Western Balkan Six (WB-6) comprise Albania, Bosnia and Herzegovina, FYR Macedonia, Kosovo, Montenegro and Serbia, with a total population of about 18 million (merely 3.6\% of EU's population) and a GDP of approx. $€ 80$ billion. An indicative deadline for admission to the EU of the two most advanced candidates - Serbia and Montenegro is 2025. This could incentivise all Western Balkan countries, including those candidates that have not yet started membership negotiations (Macedonia and Albania) and those waiting for candidate status (Bosnia and Herzegovina and Kosovo), to remove domestic political obstacles to EU accession, speed up reforms and reduce labour market gaps.

Recognizing the aims of the research, we will concentrate on testing the following hypothesis:

Hypothesis 1: There is strong positive correlation between the economic potential (measured by GDP per capita) and the labor market indicator (Average monthly gross wages) in the period 2012-2017. for six Western Balkan countries.

Hypothesis 2: The most integrated Western Balkan country (measured by the transition qualities), has the highest average monthly gross wages.

The paper is organized as follows. After introduction, the Section 1 of the paper is devoted to theSustainable Transition of Western Balkans to the European Union. In the Section 2, we give an overview of theEconomic potential of the Western Balkans measured by annual national accounts (including GDP). Labour market gaps and trends are presented in Section 3. The Section 4gives Scenario analysis for the Western Balkans countries and future priorities. The last Section concludes the paper. 


\section{SUSTAINABLE TRANSITION OF WESTERN BALKANS TO THE EUROPEAN UNION}

The transition of Western Balkans to the EU will take sustainable character if net positive effects in the long term surpass the negative effects. The speed of reducing gaps and catching up with the developed member countries depends on the degree of exploitation of economic potentials. Measures and drivers of economic catch-up with the developed countries are one of the preconditions for Western Balkans countries to successful integration process.From the perspective of economic catchup with the developed economies, the divergence threatens to slow down or even stop the catch-up process. One of the challenges facing the Western Balkans is to reduce the large differences between the center and the periphery. The European Union countries play the role of economic and political center of gravity for Western Balkans.(Stojanović, Kostić, \& Šaranović, 2018)

Western Balkan Countries' ability to assume obligations of EU membership are summarized in Table 1. Ten selected indicators (Free movements of goods, Freedom of movements for workers, Freedom to provide services, Free movement of capital, Company low, Intellectual property law, Competition policy, Economic and Monetary policy, Economic and Monetary policy, Social policy and employment, Enterprise and Industrial policy) indicate the readiness of each country to integrate and to harmonize their economic systems.

Based on the data given in Table 1, it can be concluded that the Western Balkan countries are on average moderately prepared for EU. Some level of preparation is done, but there is plenty to do in the next period.

Table 1. Countries' ability to assume obligations of EU membership

\begin{tabular}{cccccccc}
\hline Indicator & $\begin{array}{c}\text { Bosnia and } \\
\text { Hercegovina }\end{array}$ & Kosovo* & Albania Macedonia Serbia Montenegro & $\begin{array}{c}\text { Average } \\
\text { WB-6 }\end{array}$ \\
\hline $\begin{array}{c}\text { Free } \\
\text { movements of } \\
\text { goods }\end{array}$ & 1 & 2 & 3 & 3 & 3 & 3 & 2.5 \\
\hline $\begin{array}{c}\text { Freedom of } \\
\text { movements for } \\
\text { workers }\end{array}$ & 1 & 1 & 1 & 1 & 3 & 2 & 1.5 \\
\hline $\begin{array}{c}\text { Freedom to } \\
\text { provide } \\
\text { services }\end{array}$ & 1 & 1 & 3 & 3 & 3 & 3 & 2.3 \\
\hline $\begin{array}{c}\text { Free movement } \\
\text { of capital }\end{array}$ & 3 & 2 & 3 & 3 & 3 & 3 & 2.8 \\
\hline Company low & 1 & 1 & 3 & 4 & 4 & 4 & 2.8 \\
\hline $\begin{array}{c}\text { Intellectual } \\
\text { property law }\end{array}$ & 3 & 2 & 2 & 3 & 4 & 4 & 3.0 \\
\hline
\end{tabular}




\begin{tabular}{llllllll}
\hline $\begin{array}{c}\text { Competition } \\
\text { policy }\end{array}$ & 2 & 1 & 3 & 3 & 3 & 3 & 2.5 \\
\hline $\begin{array}{c}\text { Economic and } \\
\text { Monetary } \\
\text { policy }\end{array}$ & 1 & 1 & 3 & 3 & 3 & 3 & 2.3 \\
\hline $\begin{array}{c}\text { Social policy } \\
\text { and } \\
\text { employment }\end{array}$ & 1 & 1 & 2 & 3 & 3 & 2 & 2 \\
\hline $\begin{array}{c}\text { Enterprise and } \\
\text { Industrial } \\
\text { policy }\end{array}$ & 1 & 2 & 3 & 3 & 3 & 3 & 2.5 \\
\hline $\begin{array}{l}\text { Note: The scores in the table are based on the EC's assessment of a country's } \\
\text { preparedness to adopt the obligations of EU membership according to the following } \\
\text { description: (1) early stage, (2) some level of preparation, (3) moderately prepared, (4) } \\
\text { good level of preparation, and (5) well advanced. } \\
\text { Source. Systematization of the authors according to European Commission }\end{array}$
\end{tabular}

In addition, the Western Balkan region lags behind other central and eastern European countries in terms of institutional reforms. As noted by the Dabrowski \& Myachenkova by 2013, Western Balkan countries had made the same progress in reforms, measured by the EBRD transition scores, as the group of smaller central and eastern European countries (Bulgaria, Croatia, Estonia, Latvia, Lithuania, Slovakia and Slovenia) had by 1996(Figure 1).

Figure 1: Average EBRD transition scores for Western Balkans and central and eastern European countries

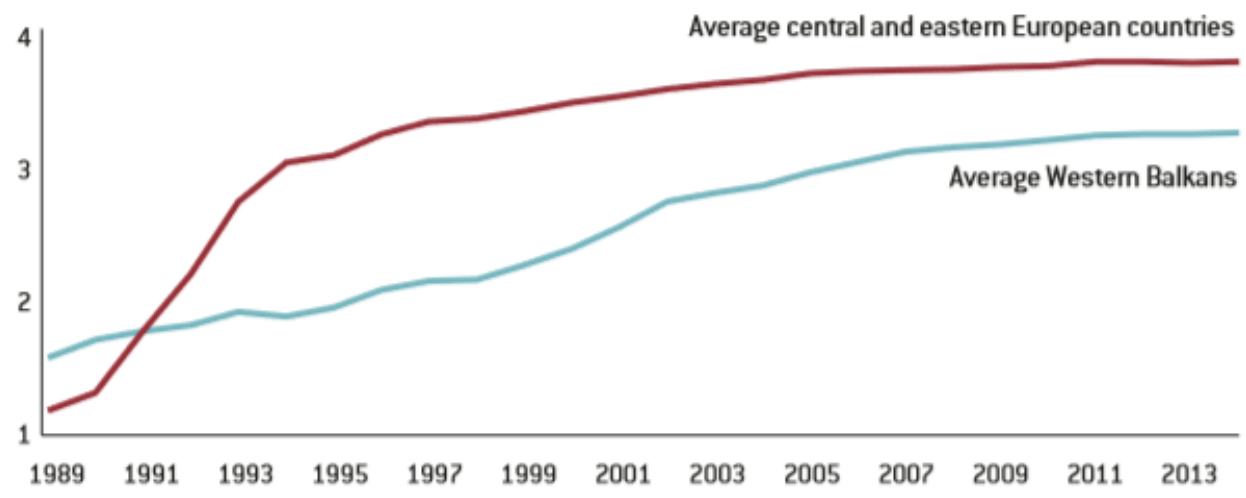

Note: Data for Kosovo is missing

Source: Dabrowski, \& Myachenkova, 2018, pp. 18.

EBRD transition score is calculated as the simple average of six EBRD indicators: price liberalisation, trade and foreign exchange system, small-scale privatisation, large scale privatisation, governance and enterprise restructuring, and competition policy, each 
rated on a scale from 1 (no reform) to 4.33 (maximum reform). EBRD defines the six transition qualities:

1. Competitive: refers to open economic systems that function well are built on dynamic and competitive markets. It represents a core characteristic underpinning the move from a state-driven, top-down mechanism to one which is more flexible and responsive to market signals.

2. Well-governed: refers to improving the quality of both state and private sector institutions and ensuring that they work well together. Governance is about the quality of institutions and the processes that they support.

3. Green dimension: refers to environmental sustainability, implying that economic decisions should reflect the full value of resources to present and future generations.

4. Inclusive: Economic inclusion, the opening up of economic opportunities to previously under-served social groups, is integral to achieving transition towards sustainable market economies. An inclusive market economy ensures that anyone can access labour markets, entrepreneurship and, more generally, economic opportunity.

5. Resilient: market economy supports growth while avoiding excessive volatility and lasting economic reversals. It is about the ability of markets and marketsupporting institutions to resist shocks, and about balance and sustainability in financial and economic structures.

6. Integrated: It enables trade at greater speed, lower cost and better quality and supports competition in product and services markets. As a transition quality, integration refers not only to the physical dimension but also improvements to domestic markets through national-level enhancements of ports, airports, cities and rural areas.

Table 2. The six transition qualities

\begin{tabular}{ccccccc}
\hline Country & Competitive & $\begin{array}{c}\text { Well- } \\
\text { governed }\end{array}$ & \multicolumn{4}{c}{ Green Inclusive Resilient Integrated } \\
\hline Montenegro & 4.89 & 5.12 & 5.15 & 5.62 & 5.93 & 5.59 \\
\hline Serbia & 4.94 & 4.39 & 5.77 & 5.16 & 5.55 & 6.39 \\
\hline Macedonia, FYR & 5.39 & 5.20 & 4.91 & 4.72 & 5.31 & 6.04 \\
\hline Albania & 4.41 & 4.31 & 4.85 & 5.11 & 4.86 & 5.76 \\
\hline Bosnia and & 4.74 & 3.66 & 4.85 & 4.83 & 5.35 & 5.47 \\
Hercegovina & & & & & & \\
\hline Kosovo* & 3.37 & 3.73 & 3.80 & 4.70 & 5.09 & 4.89 \\
\hline Minimum & 3,37 & 3,66 & 3,80 & 4,70 & 4,86 & 4,89 \\
\hline Maximum & 5,39 & 5,20 & 5,77 & 5,62 & 5,93 & 6,39 \\
\hline Average & 4,62 & 4,40 & 4,89 & 5,02 & 5,35 & 5,69 \\
\hline Standard Dev. & 0,63 & 0,60 & 0,58 & 0,32 & 0,34 & 0,47 \\
\hline Sournnyyynn
\end{tabular}

Source: Systematization of the authors according to European Bank for Reconstruction and Development 
The data shown in the Table 2 suggest that Serbia is the most integrated country which also has the best results regarding the green dimension. FYR Macedonia is the most competitive and well-govened country, Montenegro is the most inclusive and resilient. Bosnia and Hercegovina, Albania and Kosovo* have achievedtransition results below the region average.

Taking into account the data of the European Bank for Reconstruction and Development, the ranking of Western Balkans is done according to the six transition qualities (Competitive, Well-governed, Green, Inclusive, Resilient, Integrated) which have the same weight coefficients in the analysis (Figure 3).

Figure 2: Input-Output Efficiency

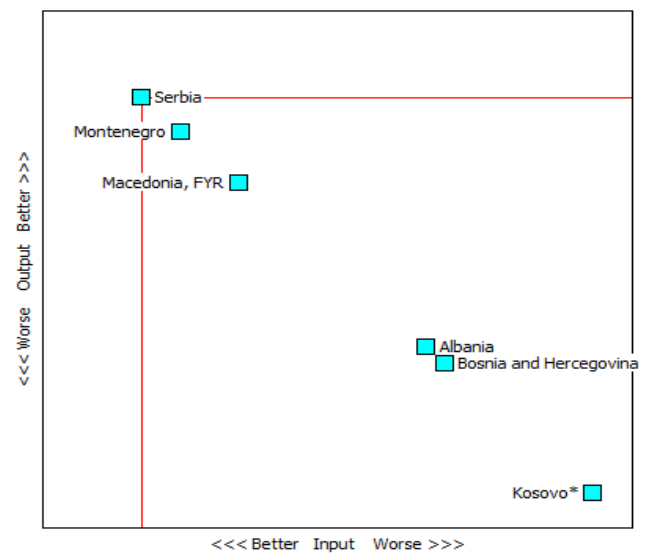

Figure 3: Walking Weights
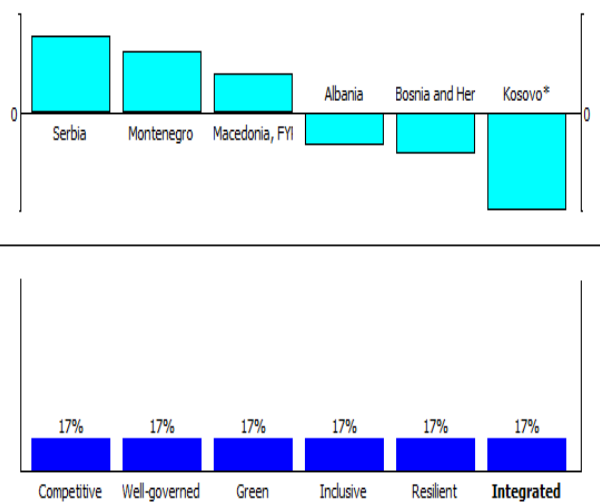

Source: Author's presentations by using software Visual PROMETHEE Academic

The results presented in the Figure 2 show that Serbia is efficient frontier and then follow Montenegro, Macedinia FYR, Albania, Bosnia and Hercegovina and Kosovo*, respectively. Albania and Bosnia and Hercegovina have achieved the similar results.

\section{ECONOMIC POTENTIAL OF THE WESTERN BALKANS MEASURED BY ANNUAL NATIONAL ACCOUNTS (INCLUDING GDP)}

The Western Balkans (WB-6) face a major convergence challenge due to current average GDP per capita for the six countries is only half the average in the $11 \mathrm{EU}$ member states of eastern Europe (EU-11), and just one-quarter of the most advanced western European countries. One of the main reasons behind this prosperity gap is the lack of appropriate factors and institutions needed for high levels of long-term productivity growth. The Figure 4 summarize GDP per capita (PPP adjusted) and order countries within sub-regions from highest to lowest. 
Figure 4. Comparative analysis of the GDP per capita (PPP adjusted) in Western Balkans and EU regions

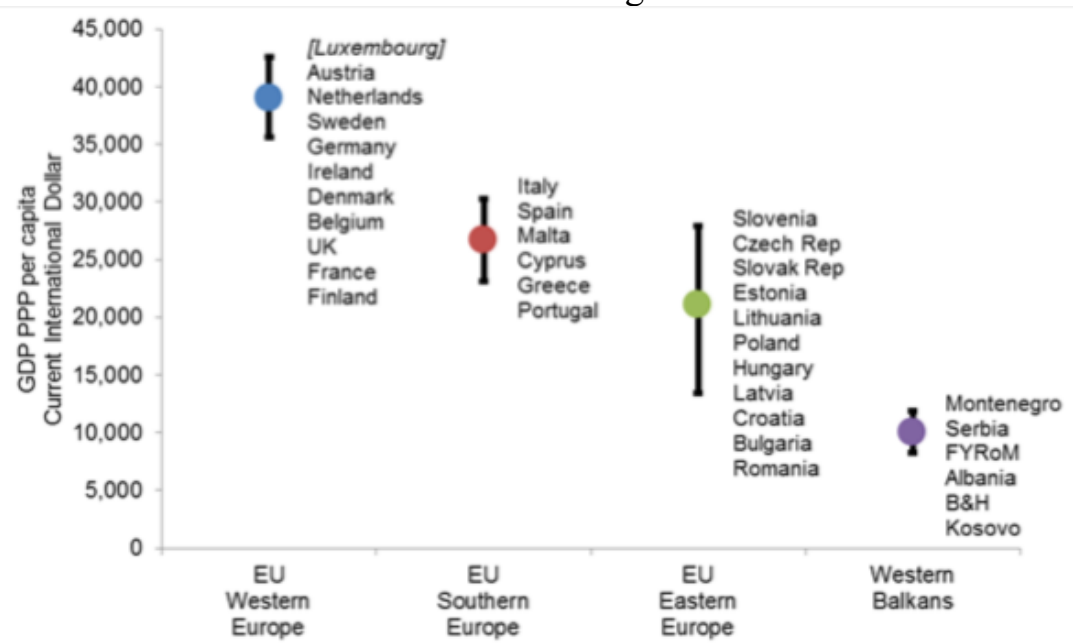

Source: Sanfey, \& Milatovic, 2018, pp.4.

Closer Economic relations with the EU, but with negative results can be explain with "reform fatigue". Western Balkan are in the group of countries that are worst off in terms of income inequality and recovery of their pre-transition GDP. Serbia, Bosnia nad Hercegovina and Montenegro have not yet reached their real 1989 GDP level. If we look at the average GDP per capita in Purchasing Power Parities (PPP) in 2016, the six Western Balkan countries had not reached 30 per cent of the level in the EU15 member states, while Central and Eastern Europe countries were at around 60 per cent of the EU15 average.

Figure 5. GDP growth (annual \%) for the six Western Balkan countries

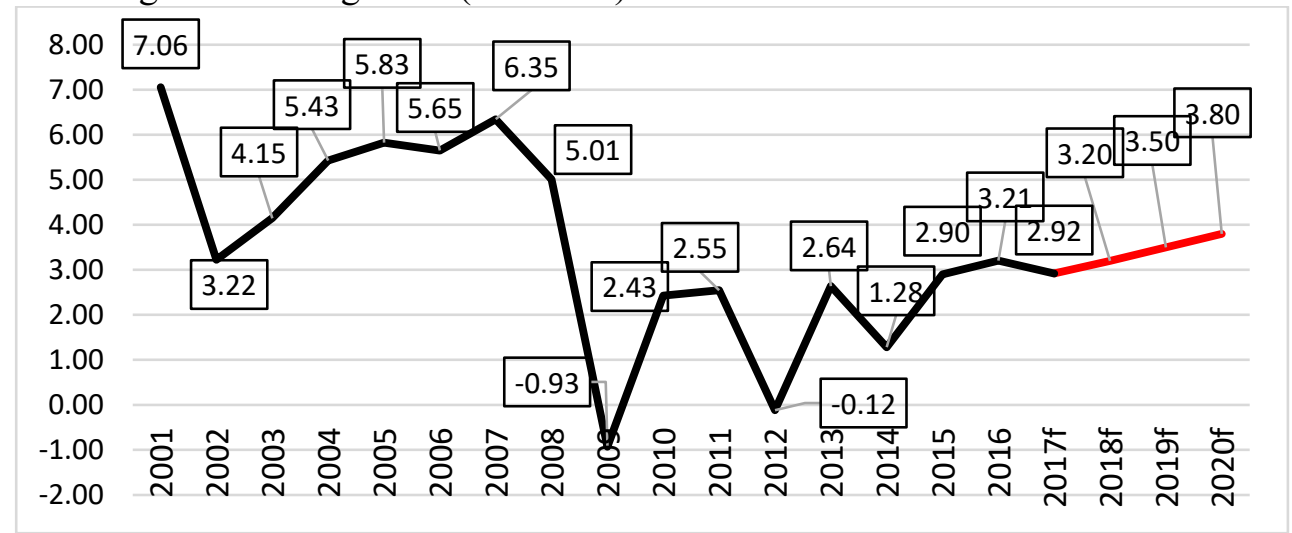

Source: Authors presentation acording to the World bank Group

Figure 5 shows annual percentage growth rate of GDP at market prices based on constant local currency (aggregates are based on constant 2010 U.S. dollars). While 
the region had seen above EU average growth rates of 5.3\% in the early $2000 \mathrm{~s}$, today these economies show volatile and slowing growth and high unemployment rates with high youth unemployment and significant brain drain. While economic performance did improve, the strong growth during 2001-08 was primarily based on the inflow of foreign capital. Projections for the period until 2020 are based on historical data in the previous period.

The clear evidence of the bad economic model in the Western Balkan coutries is an extremely high unemployment rate. The difference in the pace and the manner of the implementation of the reforms at the labour markets among the Western Balkans is one of the the main causes of the difference in the speed of the income convergence. (Stanišić, 2016)

\section{WESTERN BALKANS: LABOUR MARKET GAPS AND TRENDS}

In the period from 2012 to 2017 the Western Balkan countries have made great resuts in improving labor market outcomes. On average, regional labor markets recorded improvements in activity rates, employment rates, unemployment rates, and youth unemployment rates. In some countries (Bosnia and Herzegovina, the FYR Macedonia, and Serbia) unemployment reached historical lows in 2017.Despite promising labor market developments in this region, key challenges include low activity rates, large share of long-term unemployment (over 80 percent in some countries) and inadequate growth rates in average gross wages. Table 3 presents the positive trend in the average monthly gross wages (in EUR) in the period 2010-2017. In relative terms, there was an increase of $15 \%$ in the average monthly gross wages in 2017 in comparison to 2012 .

Table 3. Summarized labor market indicators for Western Balkans

\begin{tabular}{|c|c|c|c|c|c|c|}
\hline Total & 2012 & 2013 & 2014 & 2015 & 2016 & $\begin{array}{c}2017 \\
\text { Q2 }\end{array}$ \\
\hline Total population $(1,000)$ & 18,427 & 18,397 & 18,350 & 18,276 & 18,223 & \\
\hline Working-age population aged $15+(1,000)$ & 14,515 & 14,465 & 14,455 & 14,432 & 14,335 & 14,251 \\
\hline Employment rate (\% population aged $15-64)$ & 44.4 & 44.8 & 45.9 & 46.9 & 49.3 & 51.9 \\
\hline Activity rate (\% population aged $15-64)$ & 58.8 & 58.9 & 59.6 & 59.8 & 61.0 & 62.3 \\
\hline Unemployment rate $(\%$ labor force $15+)$ & 23.9 & 23.4 & 22.4 & 21.2 & 18.7 & 16.2 \\
\hline $\begin{array}{l}\text { Youth unemployment rate (\% labor force } 15- \\
24)\end{array}$ & 48.6 & 48.3 & 50.2 & 47.7 & 42.1 & 37.6 \\
\hline $\begin{array}{l}\text { Unemployment rate, high educated } 15+ \\
\text { (ISCED 5-8) }\end{array}$ & 17.7 & 18.0 & 17.1 & 17.1 & 16.0 & 14.3 \\
\hline $\begin{array}{l}\text { Unemployment rate, low educated } 15+ \\
\text { (ISCED 0-2) }\end{array}$ & 22.6 & 22.6 & 21.9 & 19.8 & 17.1 & 14.3 \\
\hline \multicolumn{7}{|c|}{ Earnings and unit labor costs } \\
\hline Average monthly gross wages, EUR & \multicolumn{6}{|c|}{$515,67521,67536,83542,83553,00 \quad 595,80$} \\
\hline \multicolumn{7}{|c|}{$\begin{array}{c}\text { Note: Average monthly gross wages have been calculated according to the data of } \\
\text { individual countries }\end{array}$} \\
\hline \multicolumn{7}{|c|}{$\begin{array}{l}\text { Source: Systematization and calculation of the authors according to The World Bank } \\
\text { Group \& the Vienna Institute for International Economic Studies, } 2018 .\end{array}$} \\
\hline
\end{tabular}


Wage levels differed both within the Western Balkans countries. Montenegro and Bosnia and Herzegovina reported the highest wage levels, with Albania reporting the lowest in the period from 2012 to 2017 (Figure 6)

Figure 6. Western Balkans ranking by Average monthly gross wages in the period 2012-2017.

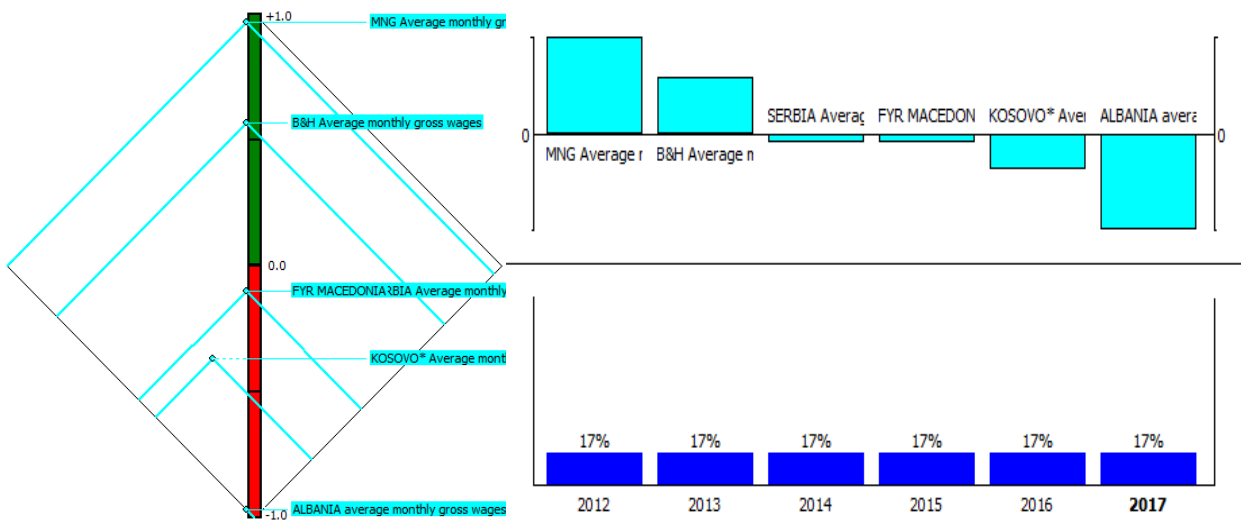

Source: Author's own presentations by using software Visual PROMETHEE

Academic

Overall, the Western Balkan countries reported high levels of growth in real wages prior to the crisis of 2007/2008, followed by a sharp decline in all countries. Following the crisis, growth accelerated in the peer countries but not in the Western Balkan countries. According to data from 2016/2017 the share of low-wage earners (defined as employees who make less than two-thirds of the median wage) was 27.3 percent in Montenegro (which was higher than in any EU country), 25.1 percent in the FYR Macedonia (the third highest), and 22.9 percent in Serbia, compared with an EU average of 17.2 percent. The share of low-wage earners was highest among younger workers (above 40 percent in Montenegro and above 30 percent in the FYR Macedonia and Serbia). (The World Bank Group \& the Vienna Institute for International Economic Studies, 2018)

Table 4: Correlations

Correlations

\begin{tabular}{|lc|c|c|}
\hline & & wages2017 & GDPpercapita2017 \\
\hline wages2017 & Pearson Correlation & 1 &, 778 \\
& Sig. (2-tailed) & &, 069 \\
& $\mathrm{~N}$ & 6 & 6 \\
\hline GDPpercapita2017 & Pearson Correlation &, 778 & 1 \\
& Sig. (2-tailed) &, 069 & \\
& $\mathrm{~N}$ & 6 & 6 \\
\hline
\end{tabular}

Pearson Coefficient values range from 0,688 (2015) to 0,778 (2017). The strongest positive quantitative connection between observed variables was achieved in 2017 (Table 4). 
The statistical technique correlation was used in order to investigate the relationship between the variables: GDP per capita and Average monthly gross wages. By calculating the Pearson coefficient for GDP per capita and Average monthly gross wages in the period 2012-2017. for six Western Balkan countries, it is concluded that there is strong positive correlation between them in all observed years.

Table 5: Selected labor market indicators by country

\begin{tabular}{|c|c|c|c|c|c|c|}
\hline Albania & 2012 & 2013 & 2014 & 2015 & 2016 & 2017 Q2 \\
\hline Labor productivity & 3.2 & 12.5 & 0.5 & -2.4 & -2.9 & 0.6 \\
\hline Monthly gross wages per employee, nominal & 2.9 & -3.2 & 0.9 & 2.8 & -2.1 & 11.0 \\
\hline Monthly gross wages per employee, real & 0.9 & -5.0 & -0.7 & 0.9 & -3.4 & 8.8 \\
\hline Unit labor costs & -0.3 & -13.9 & 0.4 & 5.4 & 0.9 & 10.3 \\
\hline Bosnia and Herzegovina & 2012 & 2013 & 2014 & 2015 & 2016 & 2017 Q2 \\
\hline Labor productivity & -0.5 & 1.4 & 2.3 & 1.9 & 5.8 & 1.1 \\
\hline Monthly gross wages per employee, nominal & 1.5 & 0.1 & -0.1 & 0.0 & 0.9 & 1.8 \\
\hline Monthly gross wages per employee, real & -0.5 & 0.2 & 0.8 & 1.0 & 2.0 & 0.6 \\
\hline Unit labor costs & 2.1 & -1.3 & -2.4 & -1.9 & -4.6 & 0.8 \\
\hline Kosovo* & 2012 & 2013 & 2014 & 2015 & 2016 & 2017 Q2 \\
\hline Labor productivity & & -7.9 & 6.1 & 13.2 & -6.9 & -4.4 \\
\hline Monthly gross wages per employee, nominal & & 3.0 & 8.6 & 5.8 & 1.8 & \\
\hline Monthly gross wages per employee, real & & 1.2 & 8.1 & 6.3 & 1.5 & \\
\hline Unit labor costs & & 11.8 & 2.3 & -6.5 & 9.2 & \\
\hline FYR Macedonia & 2012 & 2013 & 2014 & 2015 & 2016 & 2017 Q2 \\
\hline Labor productivity & -1.3 & -1.4 & 1.9 & 1.5 & 0.4 & -3.8 \\
\hline Monthly gross wages per employee, nominal & 0.2 & 1.2 & 1.0 & 2.7 & 2.0 & 2.3 \\
\hline Monthly gross wages per employee, real & -3.0 & -1.6 & 1.3 & 3.0 & 2.2 & 1.0 \\
\hline Unit labor costs & 1.5 & 2.6 & -0.9 & 1.2 & 1.6 & 6.4 \\
\hline Montenegro & 2012 & 2013 & 2014 & 2015 & 2016 & 2017 Q2 \\
\hline Labor productivity & -5.2 & 3.1 & -5.0 & 0.9 & 1.8 & 1.6 \\
\hline Monthly gross wages per employee, nominal & 0.7 & -0.1 & -0.4 & 0.3 & 3.6 & 1.8 \\
\hline Monthly gross wages per employee, real & -3.2 & -1.9 & 0.1 & -1.1 & 3.5 & -0.6 \\
\hline Unit labor costs & 6.2 & -3.1 & 4.8 & -0.6 & 1.8 & 0.2 \\
\hline Serbia & 2012 & 2013 & 2014 & 2015 & 2016 & 2017 Q2 \\
\hline Labor productivity & 0.1 & -0.9 & -6.3 & 0.2 & -2.7 & -2.8 \\
\hline Monthly gross wages per employee, nominal & 8.9 & 5.7 & 1.2 & -0.5 & 3.8 & 4.7 \\
\hline Monthly gross wages per employee, real & 1.0 & -1.9 & -1.7 & -2.4 & 2.6 & 1.0 \\
\hline Unit labor costs & 8.8 & 6.6 & 7.9 & -0.6 & 6.7 & 7.7 \\
\hline Western Balkans - 6 & 2012 & 2013 & 2014 & 2015 & 2016 & 2017 Q2 \\
\hline Labor productivity & & 1.7 & -2.0 & 1.0 & -1.4 & \\
\hline Monthly gross wages per employee, EUR nominal & & 3.6 & -0.3 & -0.7 & 1.0 & \\
\hline Monthly gross wages per employee, EUR real & & -0.5 & -1.2 & -1.4 & 0.6 & \\
\hline Unit labor costs, EUR adjusted & & 1.8 & 1.7 & -1.6 & 2.3 & \\
\hline
\end{tabular}

Note: Unit labor costs (ULC): average annual gross wages per employee relative to labor productivity (real GDP per employed person)

Source: Systematization of the authors according to The World Bank Group \& the Vienna Institute for International Economic Studies, 2018. 
A detailed overview of the selected labour market indicators (Labor productivity, Monthly gross wages per employee, nominal and real, and Unit labor costs) was given in the Table 5 by country and by whole region in the previous six years.

\section{SCENARIO ANALYSIS FOR THE WESTERN BALKANS COUNTRIES AND FUTURE PRIORITIES}

The Western Balkan countries have converged among themselves and toward European Union, but the speed of the convergence is moderated with the hit of global crisis and the recovery still seems difficult to the rate of pre-crisis. As economies in transition that are attempting to converge with the European development stages, have to go through structural evolutions.Therefore, the convergence is a dynamic process which requires a proactive policies to establish strong and reliable institutions, to guarantee political stability, to promote the business climate in order to further guide economic development and welfare. (Meksi, \& Xhaja, 2017)

According to IMF World Economic Outlook, catch-up process with EU living standards has taken place in the past 15 years and the average annual growth rate of the Western Balkans region was over 3 per cent, compared with about 1.4 per cent in the EU. However, this period can be divided into two distinct phases: the pre-crisis period (until 2008) and the post-crisis period (from 2009). There were double dip recessions in 2009 and 2012 and average WB-6 growth in this period was just 1.2 per cent, compared with 0.7 per cent in the EU. Taking into account the speed of convergence has thus slowed down markedly over the past seven years, full convergence with average EU living standards could take many decades.

Figure 7. Convergence scenarios for Western Balkans countries

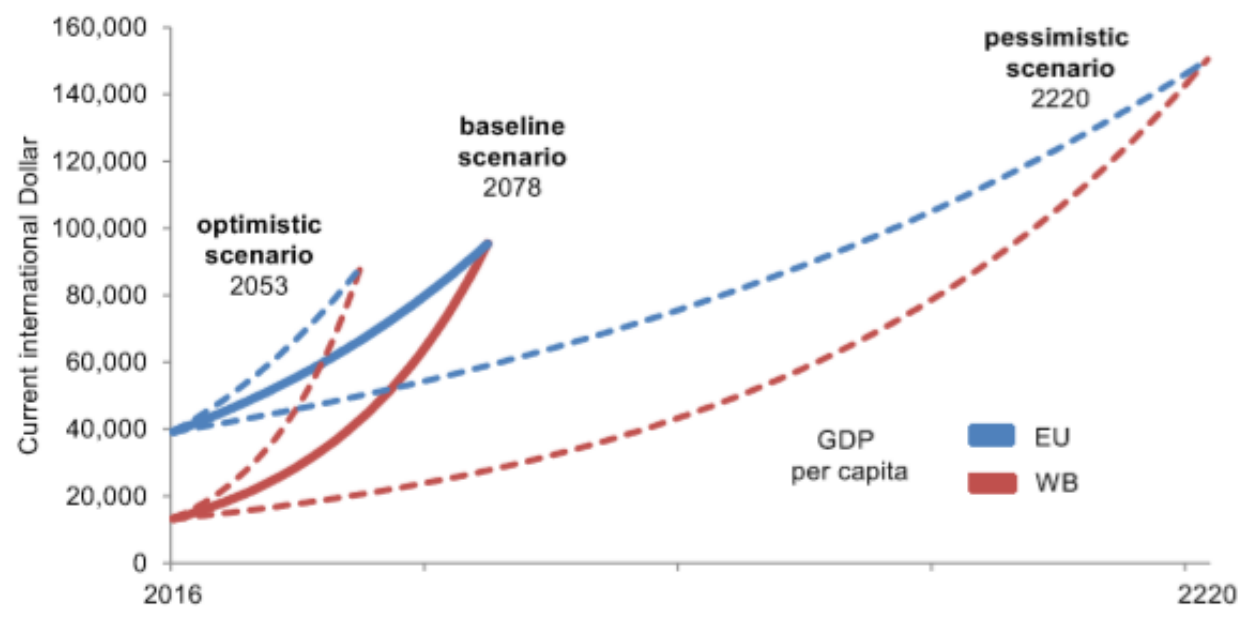

Source: Sanfey, \& Milatovic, 2018, pp.5 according to IMF World Economic Outlook 
A baseline scenario, which uses the average growth rates for the period of 2001-16, implies that the WB-6 region, on average, could achieve the average GDP per capita in the EU in about 60 years time. An optimistic scenario, which uses pre-crisis growth rates, would yield catch up with EU living standards in just under 40 years, while a pessimistic scenario, which uses the postcrisis average growth rates, means that catching up takes place after 200 years (Figure 7).

The World Economic Forum defines some priorities for the future of the Western Balkans in 2018. While there is a more upbeat forecast for accelerating growth rates in the future, three key priorities need to be addressed:

1. Strengthening growth and investment through public-private partnerships,

2. Driving a future-oriented digital ecosystem (The Western Balkans have shown a strong growth of its start-up environment and several countries have launched digital initiatives to transform their economies and societies. However, business sophistication ranks still very low in the region, which points to a lack of integration and industry density and much remains to be done to ensure the region can withstand the pressures on their job markets and deliver successful efforts to develop reskilling and technological skills in all industries),

3. Supporting next-generation leadership.

\section{CONCLUSION}

The European Union countries play the role of economic and political center of gravity for Western Balkan region. The transition of Western Balkans to the European Union will take sustainable character if net positive effects in the long term surpass the negative effects. The speed of reducing labour market gaps and catching up with the developed member countries depends on the degree of exploitation of economic potentials.

Western Balkan Countries' ability to assume obligations of EU membership are estimated by using ten selected indicators (Free movements of goods, Freedom of movements for workers, Freedom to provide services, Free movement of capital, Company low, Intellectual property law, Competition policy, Economic and Monetary policy, Economic and Monetary policy, Social policy and employment, Enterprise and Industrial policy) which indicate the readiness of each country to integrate and to harmonize their economic systems.Based on the obtain results, it can be concluded that the Western Balkan countries are on average moderately prepared for European Union. Concrete, according to the six transition qualities, Serbia is the most integrated country with the best results regarding the green dimension. FYR macedonia is the most competitive and well-govened country, Montenegro is the most inclusive and resilient. Bosnia and Hercegovina, Albania and Kosovo* have achievedtransition results below the region average. According to the value of the transition qualities scores, the order of 
the countries is the following: Serbia, Montenegro, FYR Macedonia, Albania, Bosnia and Hercegovina and Kosovo*, respectively.

In the period from 2012 to 2017 the Western Balkan countries have made great resuts in improving labor market outcomes. On average, regional labor markets recorded improvements in activity rates, employment rates, unemployment rates, and youth unemployment rates. In some countries unemployment reached historical lows in 2017. Despite promising labor market developments in this region, key challenges include low activity rates, large share of long-term unemployment and inadequate growth rates in average gross wages.Wage levels differed both within the Western Balkans countries. Montenegro and Bosnia and Herzegovina reported the highest wage levels, with Albania reporting the lowest in the period from 2012 to 2017. According to the value of the average monthly gross wages, the order of the countries is the following: Montenegro, Bosnia and Hercegovina, Serbia, FYR Macedonia, Kosovo*, and Albania, respectively.

During the research, the hypothesis 1 was confirmed due to there was strong positive correlation between the economic potential (measured by GDP per capita) and the labor market indicator (Average monthly gross wages) in the period 2012-2017. for six Western Balkan countries.Pearson Coefficient values range from 0,688 (2015) to 0,778 (2017), so the strongest positive quantitative connection between observed variables was achieved in 2017. On the other hand, hypothesis 2 was rejected due to Serbia, as the most integrated Western Balkan country measured by the transition qualities, had not the highest average monthly gross wages in the analysed period. In addition, the results of empirical research suggest thatorder of countries according totransition qualities, do not respond to order of countries according to average monthly gross wages, as one of key labour market indicators which is analysed in the paper.

This paper presents a good basis for further research due to taking into account the specificities of the Western Balkans countries on their sustainable path to the European Union. Based on possible new or expanded ways of thinking about measuring the labour market gaps, the paper summarizes relevant theoretical and practical evidence about correlation between the economic potential (measured by GDP per capita) and the labor market indicators. Combining observations and suggestions, this paper gives direct practical implications for evaluating trends in this area.

\section{REFERENCES}

1. Dabrowski, M., \& Myachenkova, Y. (2018). The Western Balkans on the road to the European Union. Bruegel Policy Contribution, 4.

2. European Bank for Reconstruction and Development. Available at: https://www.ebrd.com/home. Accessed May, 2018.

3. European Commission (2018). Communication from the Commission to the European Parliament, the Council, the European Economic and Social 
Committee and the Committee of the Regions, A Credible Enlargement Perspective for and Enhanced EU Engagement with the Western Balkans. Strasbourg.

4. Meksi, E., \& Xhaja, E. (2017). Income and structural convergence of Western Balkans to European Union. European Journal of Comparative Economics, 14(1), 139-152.

5. Sanfey, P., \& Milatovic, J. (2018). The Western Balkans in transition: diagnosing the constraints on the path to a sustainable market economy. London: European Bank for Reconstruction and Development.

6. Stanišić, N. (2016). Income convergence in the process of the Western Balkan states' accession to the European Union. Ekonomski horizonti, 18(1), 3-14.

7. Stojanović, B., Kostić, Z. \& Šaranović, J. (2018). Integration engineering and convergence of the GDP per capita in the European Union and the Eurasian economic union. Book: Economic Integrations, Theory, Cooperation and Perspectives; Integrations reforms and business challenges. pp. 203-213.

8. The World Economic Forum. Available at: https://www.weforum.org/agenda/2018/05/why-we-need-to-stabilise-the-westernbalkansAccessed May, 2018.

9. The World Bank Group \& the Vienna Institute for International Economic Studies. (2018). Western Balkans Labor Market Trends 2018.

10. The World Bank Group. Available at: http://www.worldbank.org/ Accessed May, 2018. 